\title{
60 Seasons \\ A Conversation Around the Future of Food
}

\author{
by Jeannette Breward \\ BFA (HONS.) Photography \\ Ryerson University, Toronto Ontario, 2015.
}

A thesis presented to Ryerson University in partial fulfillment of the requirements for the degree of Master of Fine Arts in the

Program of Documentary Media.

Toronto, Ontario, Canada, 2017.

(C) Jeannette Breward 2017

Submitted to:

Pierre Tremblay

Don Snyder

Katy McCormick 


\section{AUTHOR'S DECLARATION}

I hereby declare that I am the sole author of this MRP. This is a true copy of the MRP, including any required final revisions. I authorize Ryerson University to lend this MRP to other institutions or individuals for the purpose of scholarly research. I further advise Ryerson University to reproduce this MRP by photocopying or by other means, in total or in part, at the request of other institutions or individuals for the purpose of scholarly research. I understand that my MRP may be made electronically available to the public. 


\section{ABSTRACT}

The current state of food production in the Western world is leading to the devastation of our land, soil, and air. Industrial farms are contributing not just to poor human health, but to the ever increasing depletion of our natural resources, a reduction in the biodiversity of plants and animals and in the sustainability of the planet. 60 Seasons - A Conversation around the Future of Food aims to stimulate the dialogue around healthy and sustainable means of food production by depicting the efforts of two small groups within Northumberland County, Ontario. Their aim is to bring sustainable farming methods to their community, while expanding the discourse around environmentally sound food production and providing healthy food choices to those in need. 


\section{ACKNOWLEDGMENTS}

I would like to thank my supervisors, Pierre Tremblay Don Snyder and Sara Knelman, for their guidance and support throughout the course of the production of this work.

I would also like to thank Tony and Linda Armstrong, Craig Smith and Peter Gabany, and all of the individuals involved with both Punk Rock Produce and the Port Hope Fare Share Food Bank for their graciousness and openness, as well as their eagerness to embrace this film and support its development.

And above all, a thank you to my friends and family. To my mother - Laurie Stata, and my husband - Jordan Breward -without your constant reassurances and support, this entire accomplishment would never have come to fruition. And to my brother - Matt Stata - for the long hours of work and patience that he spent creating the beautiful score for the film. 


\section{TABLE OF CONTENTS}

AUTHOR'S DECLARATION................................ii

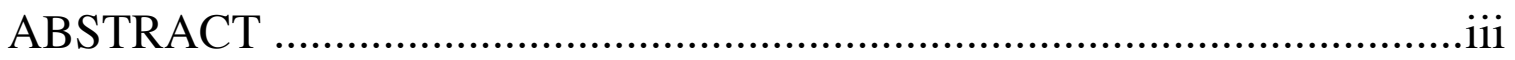

ACKNOWLEDGEMENTS ..............................................

THE PROBLEM

Industrial farms, monocultures and sterile seeds. Our current food crisis

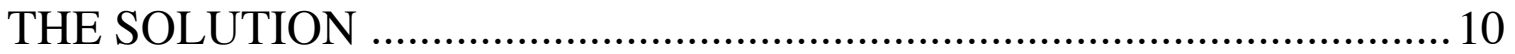

A LOOK AT PERMACULTURE AND SUSTAINABLE FARMING

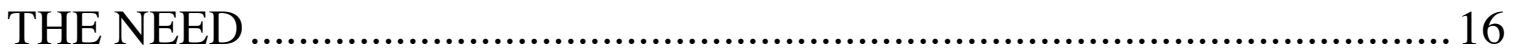

a brief history of food banks in canada and their current state

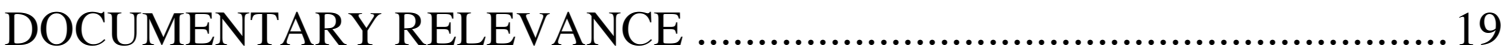

METHODOLOGY .........................................31

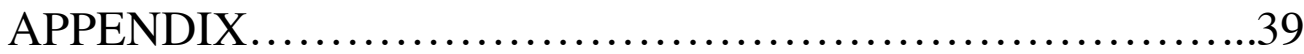

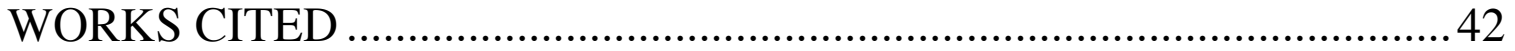

ADDITIONAL RESOURCES.....................................45

\section{LIST OF FIGURES}

Figure 1: Food Bank Use in Canada by the Numbers.........................19

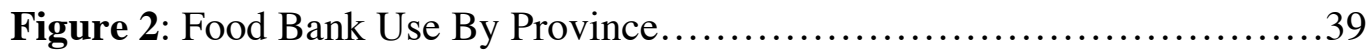

Figure 3: Individuals Accessing Food Banks Per Month........................39

Figure 4: Headwaters Satellite Image.........................................40

Figure 5: Headwaters Location..........................................40

Figure 6: Punk Rock Produce Satellite Image ...............................41

Figure 7: Punk Rock Produce Location.....................................41 


\section{THE PROBLEM}

The dominant means of food production in the western world today is run primarily by large corporations. The majority of the food that we consume is produced en masse by corporate owned, massive factory farms. This is a process that we as consumers, in general, are completely removed from, largely unaware of and unknowingly contributing to. These factory farms are not only producing potentially harmful food products - which include livestock that is full of hormones and antibiotics - they are also incredibly devastating to the surrounding environment. But it doesn't have to be this way. 60 Seasons is a portrait of the small community of Northumberland County - specifically focused on Port Hope, Ontario, and the efforts of two groups of individuals within the community to bring locally, ethically, and sustainably grown food to its citizens. Though these are just two small case studies, they are representative of a much larger movement that is growing in numbers. It is a movement of likeminded individuals who are passionate about food production and environmentalism: people who aim to turn the tables back to a time when food was grown and raised by individuals and families, not by corporations. They strive towards a food and farming revolution. Their goal is not just to improve the health of those consuming the food, but the health of the planet that we all share. They aim not only to help bring food security to the fellow members of their community by donating healthy produce to the local food bank, but also to raise 
awareness and knowledge of food production through workshops and seminars geared towards educating the population on the ease with which they can grow, preserve, and prepare their own food. We can, and should, take food production back into our own hands. The future of our planet may just depend on it. Headwaters Farm and Punk Rock Produce have made it their mission to do just that.

Humanity, as a whole, has seen a rather drastic shift in the way we produce our food since the beginning of the agricultural food revolution and the domestication of plants and animals. Although changes to our agricultural processes have been made in the name of progress, they are unfortunately causing much more harm than good. The modern model of capitalism has taken over the majority of food production. Capitalism's focus has always been on maximizing the amount of profit in the least amount of time. It is because of this focus on profit above all else that many other important factors in the sustainability of our food system and, in turn, of our planet, are being ignored. These outside factors are not considered important by corporate food producers, and are therefore not accounted for in their process of producing food en masse as cheaply as possible.

In order to maintain the delicate balance of our food system as well as the finite resources of the planet that we depend on, a change must be made. We need to move towards a more sustainable method of farming. This change must be made by individuals in their own food choices but more importantly, by our government. Farming subsidies that are in place from the government are currently given based on the highest level of 
production. Because of this, all of the government support is given to large factory monoculture farms. Small, sustainable farms have no way of competing with the production levels of giant, corporate run, monoculture farms, and are therefore unsupported financially by the government. Therefore, we are supporting the farms that are doing the most damage. Our current, dominant model of corporate, industrial agriculture is a major contributing factor to the current food crisis. The continued growth and support of large factory farms, the creation of genetically modified organisms and the steadily diminishing presence of smaller family run farms is damaging to our individual food. We have a strong and urgent need to support a movement towards a more sustainable system of agriculture within our culture.

In order to maintain both our planet's delicate ecosystem and our food sovereignty, a sustainable means of agriculture is required. This system of agriculture needs to not only provide us with the means to satisfy human hunger for the growing population or our planet, but it must also strive to maintain and enhance environmental quality, natural biological cycles and must aim to make the most effective use of our nonrenewable resources in order to maintain and enhance the sustainability of our planet. Although corporate-run monoculture factory farms, whose focus is on the production of only a few agricultural products, such as corn, wheat, and beef, do work to satisfy our growing food needs, they are most certainly not contributing to the other important aspects of sustainable agriculture; in particular, the enhancement and maintenance of the environmental quality of the planet. In these large-scale monocultures, the huge, daunting amounts of livestock being raised produce a staggering amount of waste on a 
much larger scale than ever before. In smaller-scale, sustainable farms, a closed loop system is utilized, where much smaller amounts of livestock waste are composted and used as fertilizer to both re-enrich the soil for future years of use, and to enhance the production of crops. ${ }^{1}$ However, in large-scale factory farms, the vast amount of waste that is being produced from the staggering number of animals being raised is full of both antibiotics and hormones that have been fed to the livestock in order to gain faster growth of the animal or increased milk production. One such common additive is the Bovine Growth Hormone(rBGH). The addition of these additives to the livestock then, in turn, leads to environmental contamination of water, soil, and even the food crops as the waste from the animals still contains active forms of these supplied anti-bacterial agents. These hormones have harmful effects in humans through both the exposure to the contaminated environment and the consumption of meat and milk produced from these factory farmed animals. Furthermore, the animal waste then produces greenhouse waste and gas emissions. ${ }^{2}$ This agricultural model of the corporate-run factory farm is therefore a major contributor to planet-wide environmental concerns such as climate change and global warming, as well as a detriment to human health, and a large factor in the contamination of our environment. It is clear to see that our agricultural model is not only unhealthy for individuals who are consuming factory farmed food products as their sole means of

\footnotetext{
${ }^{1}$ Koç, M., Sumner, J., Winson, A. (2012). Critical Perspectives in Food Studies. Don Mills, Ontario: Oxford University Press.

2 Viegas, I., Santos, J. M. L., Barreto, A., Fontes, M.A. (2011). Meat Safety: A Brief Review of Concerns Common to Science and Consumers. International Journal of Sociology of Agriculture and Food, Volume 19, 275-288
} 
sustenance, but also for the continued growth and usability of our planet for future generations.

Another, more recent change to the way in which our food is produced is the invention and implementation of genetically modified organisms. This term refers to any plant or animal species that has been genetically engineered with DNA from other sources such as bacteria, viruses, or differing plants and animal species that are not crossed naturally within nature. ${ }^{3}$ This development is being touted as a means of progress due to it's ability to supposedly produce greater amounts of food for the population. These genetically modified seeds are purposefully being engineered to be resistant to pesticides, which allows for weeds to be eradicated within the fields with no effect on the crops around them. It is important to consider the detrimental effects of this new method of production. Firstly, these genetically modified seeds are purposefully engineered to be sterile. This means that fruit and vegetables grown from these seeds will not germinate and cannot be reused by farmers in future years. Saving seeds from a previous year's yield in order to reuse in next year's growing season is vital to smaller scale, sustainable, and family-run farms. It is key to a sustainable method of food production. It is clear that removing this seed saving potential from plants is entirely profit driven - farmers are forced to buy more seeds each year in order to continue to grow their crops. These seeds, known as "terminator seeds", then cross-pollinate and contaminate surrounding, non-sterile crops. It is clear that by producing these sterile plants, the future of our food supply is being put in immediate danger. It renders the

${ }^{3}$ Koç, Critical Perspectives in Food Studies. 
practice of seed saving used and relied on by famers completely impossible, and often times even illegal as a violation of Monsanto's patent protection. GMO producer Monsanto is known to monitor fields in search of violating small farms to sue. ${ }^{4}$ Through the contamination of renewable seeds, eventually all seed production will belong to large companies like Monsanto, and be removed from the ownership of farmers themselves. New seeds will therefore need to be purchased by farmers again every year. ${ }^{5}$ This shows another clear example of how industrial agriculture is rapidly reducing our society's food sovereignty by taking control of the agricultural industry away from the people and placing it in the hands of large-scale corporations. It is unethical for a company to be able to own a plant, which is the course that Monsanto is on. As individuals, we have the right to grow, pick, and eat the food of our choosing. If this method of production continues, it will not be long before consumers no longer have the option of choosing to eat or to grow organic, non-GMO food. Seed sovereignty, or the right to own, save, and produce our own seeds for food production, is a key element in the future of sustainable farms. To take this right away from farmers is to make a drastic change to the way that food has been grown for centuries. It is something that needs to be halted before our food is solely owned and regulated by one company. It is a dangerous direction to be taking, and something that more attention needs to be drawn to.

\footnotetext{
4 Scanlan, S.T. (2013) Feeding the Planet or Feeding Us a Line? Agribusiness, "Grainwashing" and Hunger in the World Food System. International Journal of Sociology of Agriculture and Food, Volume 20, 357-382

${ }^{5}$ Koç, Critical Perspectives in Food Studies.
} 
There is another important element to consider when discussing the downside and dangerous effects of the continued growth of the genetically modified food industry. As the development of pesticide resistant crops increase, the use of chemicals on fields to fight off weeds also increases. Monsanto provides a crop known as Roundup Ready canola. This strain of canola seeds is resistant to the weed killer Roundup, and it is rapidly monopolizing crops. The use of this seed allows more pesticides to be used on the fields in order to fight weeds and control pests. With this increased use of pesticides comes the pesticide treadmill effect. This is a term that is used to describe the evergrowing need for newer, and increased amounts of pesticides, as the pests that they are fighting off develop a resistance to the chemicals over time with their increased use. ${ }^{6}$ It is becoming clear that GMOs are putting our food security at risk, and posing long term negative effects to the future of our planet.

Furthermore, with the advancement of our current capitalist, industrial model of agriculture we are witnessing a steady decline in the prominence of the family farm, along with the elimination of such small productions by larger-scale production. As corporate-owned farm monopolies steadily tighten their hold on the agricultural industry, smaller, family-run farms will continue to suffer. As the introduction of new technologies is becoming more frequent, the need to expand their operations is ever rising, and the need to repurchase seeds with every new season as a result of their sterile nature, so family farmers are falling further into debt simply in an effort to keep up with the rapid growth of industrial agriculture. The small-scale farmer's current debt to income ratio is

\footnotetext{
${ }^{6}$ Koç, Critical Perspectives in Food Studies.
} 
at an all-time high, with the average farmer owing $\$ 23$ dollars of debt for each dollar of income that they earn. ${ }^{7}$ Naturally, this rapid increase in debt all but eliminates the appeal of taking over the family farming business for future generations. In a community where the majority of farms are typically passed down through generations in order to maintain their operations, it becomes easy to see why these small farms have all but vanished. ${ }^{8}$

Despite this growing agricultural crisis, our government continues to support corporate-run farms. They are still granting farm subsidies based solely on the size and production of the farm, thereby providing financial aid to corporate farms that are already thriving, while small productions continue to suffer. By reinvesting its money back into large-scale corporate-run farms, small family farms will continue to be undermined by their own government. ${ }^{9}$ As family farms still must rely heavily on the capitalist industry, their numbers will consistently dwindle as a handful of giant corporations increase their hold over the production of our food. Due to this model of production, our food choices are being drastically limited and our farming community is suffering.

Our currently dominant, capitalist-based model of industrial agriculture is in desperate need of reform. Though it was implemented as a supposed means of increasing the production of food, and touted as a way to help end hunger, its focus is not on the people it aims to feed, but rather is solely on profit. Many important factors in food production,

\footnotetext{
7 Ibid.

8 Bjørkhaug, H., Ronningen, K. (2011). Global Shocks, Changing Agricultural Policy and the Viability of Rural Communities. International Journal of Sociology of Agriculture and Food, Volume 21, 1-6

${ }^{9}$ Koç, Critical Perspectives in Food Studies.
} 
such as the potential harms to both the environment and to human health, are ignored in order to focus primarily on the increase in profitability. When looking at the continued growth and government support of corporate-run, large-scale monoculture farms, the creation and wide spread distribution of genetically modified organisms, and the rapid diminishing of family run farms, it becomes quite clear that our current agricultural model is a major contributor to the global food crisis. It is causing significant damage to both the world's food sovereignty and the planet's environmental sustainability.

\section{THE SOLUTION}

As detailed above, the problems with the current dominant method of food production are clear. The purpose of 60 Seasons is to highlight some of the ways in which individuals are working to incite change towards a more natural and sustainable method of food production, both for our health as a species, and for the future of the planet as a whole. The goal is to enter a state where the world develops an ethical foodscape - that is, a realm where good food is not simply viewed as an individual indulgence, but as something that is connected to collective obligations we all have as a species such as sustainability, animal welfare and social justice. The UN issued a report titled "Our Common Future" in 1987, within which they defined sustainability as "meeting the needs of the present without compromising the ability of future generations 
to meet their own needs". ${ }^{10}$ It is clear that this is not the focus of our current, corporaterun agricultural model. The devastating effects that this profit-driven system has on both the environment and our individual health will certainly have long-reaching consequences for future generations.

If we do not begin to act to bring about a food revolution, the impact on the planet will be far-reaching and long lasting. In 2014, on the first World Soil Day, a UN official of the Food and Agricultural Organization informed a forum that over one third of all of the world's usable soil has already been degraded. She warned that, without intervention and the adoption of new farming approaches, the world would only have sixty growing seasons left before all of the useable top soil is gone. ${ }^{11}$ This is where the inspiration for the title of the film was drawn from. It is a number that hits home - this is not something that we can put off for future generations. It is not a problem that will only see disastrous results in some distant, easy to ignore, future. It is something that will be affecting many of us that are alive today - and certainly dramatically affecting the children of this generation. Change needs to be happening now, or it will be too late. When the message being put out to the world about food production is largely controlled by those who benefit from the current agricultural model, we must take action into our own hands to put out a counter message. This notion is something that the creators of

10 Belott, Anne. "Modeling Sustainable Food Systems - The Permaculture Research Institute." The Permaculture Research Institute. 2016. http://permaculturenews .org/2016/11/24/modeling-sustainable-food-systems/.

11 Arsenault, Chris. "Only 60 Years of Farming Left If Soil Degradation Continues." Scientific American. 2014. https://www.scientificamerican .com/article/only-60-years-offarming-left-if-soil-degradation-continues/. 
both Headwaters Community Garden and Punk Rock Produce are incredibly passionate about. To both, the solution is sustainable methods of food production and education of the community at large.

The method of farming used by Headwaters farm is one known as Permaculture. A combination of the words "permanent" and "agriculture", Permaculture is defined as "an approach to land management that creates high-yielding, low-energy, selfperpetuating systems by which the functions of animals, plants, humans, and Earth are integrated to maximize their value and create sustainable human habitats." ${ }^{12}$ The term itself was originally coined in 1972 by Bill Mollison - an Australian scientist, researcher and author. ${ }^{13}$ It was originally a term created and used within the farming community but its use has moved on to spaces outside of the conventional farm - including urban gardening, shelter design and architecture. It is now thought of more as a combination of the words "permanent" and "culture", as it expands far beyond simply agricultural applications. Permaculture is about more than simply farming. Beyond food production, it is also working within the areas of building structures and shelter, water, energy and waste management. Permaculture aims to "maximize a site's productivity, while maintaining ecosystems and restoring damaged land to a healthy, life-promoting state." 14

The goal of permaculture is to make use of a closed-loop system - a system through which all matter and energy is maintained, contained, and reused within the

12 Bortman, Marci, Peter Brimblecombe, and Mary Ann Cunningham. "Permaculture." Environmental Encyclopedia , Vol. 2. 3rd ed. Detroit: Gale, 2003. p1065-1067. 2003. 13 Ibid.

14 Ibid. 
growing cycle. It is an energy-efficient system where nothing is wasted. Waste products from plants and animals are reintroduced back into the system to enrich the soil and benefit future growth cycles. This re-enrichment of the soil is one of the most important elements when prolonging the usability of our earth's finite resources. As noted above, if we wish to have more than simply sixty seasons of usability left from the world's soil, we must work to prevent future degradation, as well as making a conscious effort towards reversing the damage that has already been done to the land. Furthermore, with permaculture gardening, self-seeding plants and perennials are utilized as they continue to perpetuate themselves through each year's harvest, and spread to become a natural 'food forest'. This term refers to a wild garden bed that produces those plants that thrive and do well in the natural climate in which it is grown. These 'food forests' are intended to consist entirely of edible plants that are able to maintain their growth cycle with minimal human intervention. In essence, permaculture gardens are defined by a few distinct factors. They are food systems that are designed to make the best possible use of the natural environment and systems that are already present, have minimal or no waste, and create a diversity of plant life within the space.

In turn with permaculture and food forest systems being put in place to grow crops, Headwaters and other sustainable farms also make use of a technique known as rotational grazing. With this method, the livestock of the farm are moved throughout the pastures each day. Typically, a smaller animal, such as chickens, would follow after the path of larger livestock species like cattle. By doing so, the chickens scratch through the waste left by the cattle, helping to release its nutrients back into the soil. At the same 
time, they are digging through the pasture and eating possible pests that could have a potentially negative impact on the usability of that space for future crops if they were not removed. The system also benefits the birds themselves as they have a wider access to natural food sources within the pasture, which in turn can aid with cutting down on feed costs for the farmers. This system is in direct opposition to the methods used in industrial agriculture.

In our prominent method of agricultural production utilized by large-scale factory farms, monocultures are grown - full fields of one specific type of crop, such as corn or soy. Permaculture argues that these types of systems cannot make full use of the resources and energy that are available within the growing space, and are therefore incredibly wasteful. Monoculture is also leading to a major reduction in the diversity of our plants and animals. As factory farms determine what they deem to be the most effective type of chicken to raise for meat, for example, that is the only meat bird that will be farmed. Industrial agriculture companies such as Monsanto claim that low-tech agricultural methods simply cannot produce enough food to feed the hungry of the world. Their solution is therefore to use technology-heavy and pesticide-based methods of farming in order to gain the most yield of a product from the land within the shortest time period. However, a lack of food is not the root cause of hunger. In fact, the UN Food and Agriculture Organization's studies show that our food supply is actually in a state of abundance, not one of scarcity. ${ }^{15}$ The problem, in fact, stems more from these industrial

15 Kimbrell, Andrew. The Fatal Harvest Reader: The Tragedy of Industrial Agriculture. Washington: Published by the Foundation for Deep Ecology in Collaboration with Island Press, 2002. 
farms themselves. By displacing farmers from their land and working towards denying them the right to grow their own food through the production and regulation of sterile seeds, they are gradually decreasing the population's food independence. But beyond that, a problem arises with the choice of crops that these corporate farms are producing en masse. Rather than farming food staples that would feed the hungry, corporate-driven farms choose instead to focus on large fields of high profit food items such as beef, corn and soy that are typically exported to wealthy countries for maximum profit. ${ }^{16}$ So, land that could be used by small scale farms to grow diverse food staples to contribute to aiding the hungry in the community is instead bought out and taken over by corporate run monoculture farms. These farms are then growing high profit food items - most likely to be used as feed for animals - that are being exported to other countries.

It is obvious that this method of food production does not actually have the hungry of the world in mind. Not only is this method not striving to feed the hungry, it is also detrimental to the earth itself, and putting our soil at risk. By planting the same crops in the same place every year, monocultures deplete the soil of its natural nutrients, alter its structure and reduce its natural ability to retain water. In turn, this leaves the soil weak and unable to support future plant growth. This leads to the increased use of chemical fertilizers in an attempt to make the soil usable again, which further degrades the quality of the soil. The Food and Agriculture Organization of the United Nations has stated that

16 Ibid. 
"Soil degradation in agricultural systems is directly related to the overuse of fertilizers and pesticides, the removal of the crop residues from the soil surface and the use of heavy machinery. Additionally, nutrient depletion is related to the absence of the fallow period in intensive agricultural systems and to the practice of ... which deplete soil nutrients due to static nutrient demand. Therefore, crop rotation is critical to preserving and eventually improving soil health." 17

It is clear that our current dominant system of agriculture is broken. Not only is it not achieving its supposed goal - that of producing more food to feed the hungry - it is also creating long lasting, devastating effects to our natural world that will only lead to further hunger in the future as our earths soil becomes unusable.

\section{THE NEED}

As noted earlier, the need to reevaluate our food system is immense. The damage to our environment that is continuing at a rapid pace should be clear evidence that our current corporate -run, industrial agriculture model is failing the future of the planet. But beyond the environmental devastation that this farming system is perpetrating, it also is not succeeding at the one goal it claims as its prime motivating factor - feeding the hungry. Despite the ever-growing quantity of crops being produced, the increasing number of modifications to our seeds and produce and the chemical treatments being put into the earth, the problem of hunger is not being solved. Focusing on our own community specifically, hunger has not been decreasing in Canada with the introduction of genetically modified organism, industrial monoculture farms, or animals raised rapidly for consumption through the addition of hormones and antibiotics.

${ }^{17}$ FAO. "Soils Are the Foundation for Vegetation." (PDF File). Food and Agriculture Organization of the United Nations. 2015. http://www.fao.org/3/a-i4666e.pdf. 
This can be seen by examining the creation of, and rise in need for, food banks within Canada. Originally established in the 1980 s, these national charity systems aim to provide free food to those living with food insecurity across the country. They are run on a volunteer and donation basis, as there are no federally established programs to assist with either funding of the food banks, or with their food supply. In fact, volunteer-run food banks and charities are the only support system in place to aid those who are suffering from a lack of food security in Canada, as there are no government run food assistant programs in place. ${ }^{18}$ Upon their initial creation, food banks were originally established to be a temporary, emergency measure to help the population recover from a recent recession. However, despite this original intention, the need for food banks has not abated as the economy began to improve. In fact, the opposite has happened. Not only are food banks still abundant throughout the country, but also the need for their assistance has actually grown, not diminished. According to Food Banks Canada, over 850,000 individuals turn to food banks across Canada for assistance every month, with over 300,000 of those being residents of Ontario. ${ }^{19}$ (see Fig. 1) Looking specifically at data from the Food Banks Canada's Hunger Report, in March of 2016, 863,492 people received food from a food bank, which is up $1.3 \%$ from 2015, and a staggering $28 \%$ higher than in 2008, with 8 out of our 10 provinces seeing an increase in numbers. ${ }^{20}$

\footnotetext{
18 Tarasuk, Valerie, Dachner, Naomi, Loopstra, Rachel, (2014),"Food banks, welfare, and food insecurity in Canada", British Food Journal, Vol. 116 Iss 9 pp. 1405 - 1417

19 "Food Banks Canada." Food Banks Canada. 2016. https://www.foodbankscanada.ca/.

${ }^{20}$ Food Banks Canada (2016). HungerCount 2016. Toronto: Food Banks Canada.
} 
Looking specifically at Northumberland County, the district of Ontario that is represented in 60 Seasons, its numbers have also jumped dramatically. When the Northumberland Fare Share Food Bank was first established in 1986, it fed 50 individuals. Now, in 2016, that number has jumped to 2,000 people. It is this food bank specifically that Craig Smith wanted to help support when he conceived the idea of Punk Rock Produce. With a strong desire to help his community and fill the gaps in food security that agribusinesses are causing, he set about providing organically grown, locally sourced food staples to the Northumberland Fare Share. In one growing season, in a small 600 square foot space that had formerly been a parking lot for a long-abandoned bar, he, with the help of community volunteers, managed to provide over 600 pounds of fresh produce to those in need. Imagine the success that could come from larger plots? Ones that have been given support from their local government to aid in the growing of sustainable food for their people? These are the movements that should be receiving funding: sustainable and permaculture farms, organic community gardens, places where real health is encouraged, real sustainability is promoted and taught, and where food security is the real goal. 


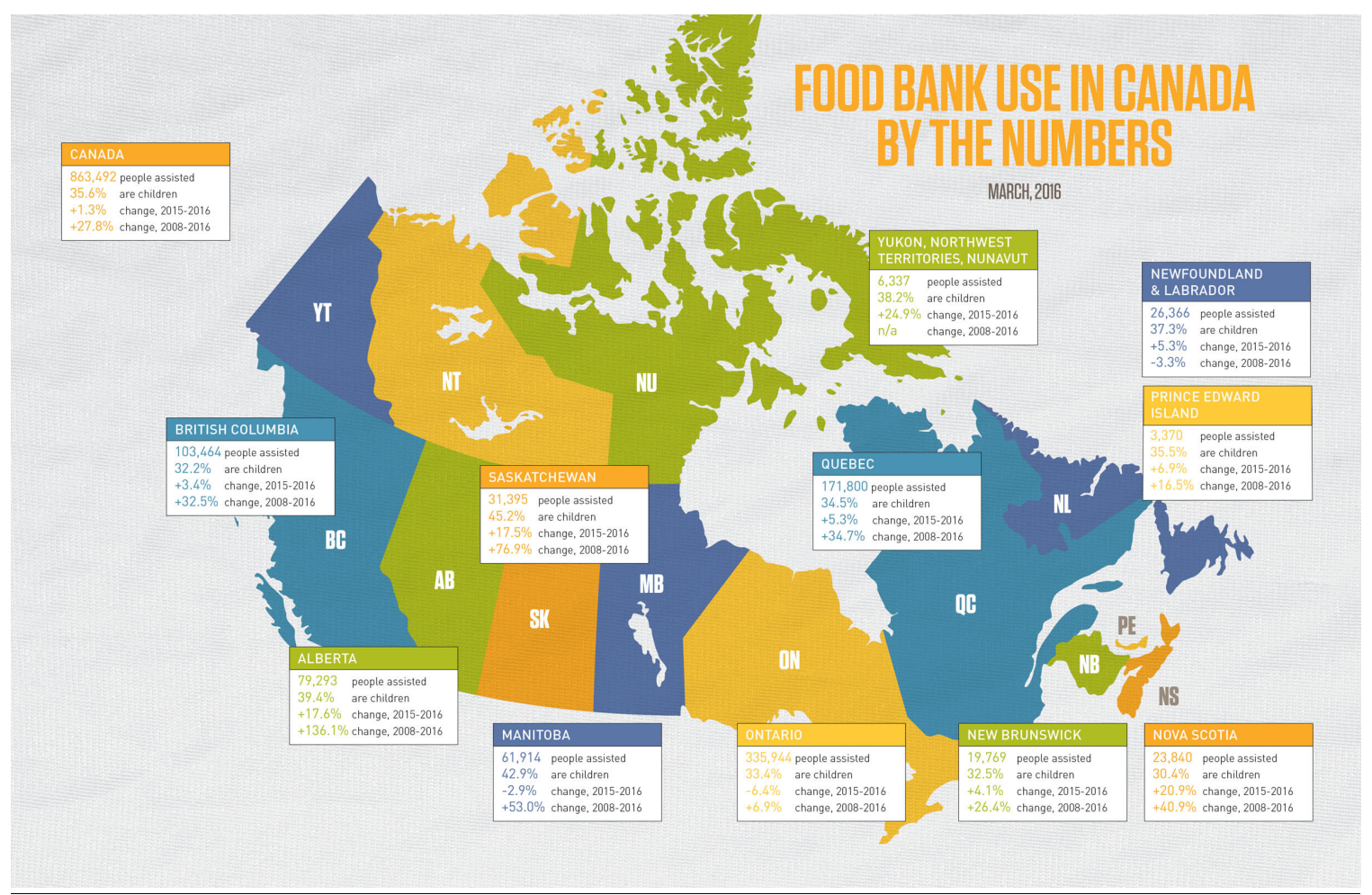

Figure 1

\section{DOCUMENTARY RELEVANCE}

From its conception, the documentary medium has been used for purposes beyond just the telling of a story. It is a way to convey a message, draw attention to an issue, and reach a larger audience with important information. It is this desire to enact change, in large part, that sets the documentary form apart from its fictional film counterparts. Activism has found a more widespread means of communication through the documentary film. Though 60 Seasons is a multifaceted film that draws inspiration from different styles of documentary work, first and foremost, it is an activist film based upon the ideals of environmentalism and sustainability. The primary goal of this film is to convey a message - one about the importance of 
protecting our planet through sustainable means of food production. It is about supporting the food security of our fellow man and providing healthy food that is healthy not just for the individual eating it, but healthy for the planet we all inhabit.

Documentaries addressing environmental activism have been growing in numbers. With films such as Al Gore's An Inconvenient Truth - a documentary addressing the dangers of global warming - bringing in more mainstream audiences to the medium, more films in a similar vein are being produced. As knowledge grows about the dangers of corporate farms, genetically modified seeds, and mass monoculture farms, a desire grows to further this education to a wider audience. There has been an influx of films geared around these topics from which I have drawn inspiration for 60 Seasons. These films provide not only a basis of ideas that I found successful and helpful to the direction of my own film, but also those whose path I found less effective, which helped determine the kind of film that I knew I did not want to be making. This helped to hone the direction that 60 Seasons would take, and led to me carving out the path that I wanted the film to take.

There are a number of recent films that tackle the problems with industrial agriculture. One such film is Cowspiracy- The Sustainability Secret, a documentary released in 2014. Cowspiracy follows the journey of the documentarian and filmmaker Kip Anderson as he challenges the current model of industrial agriculture and the devastating effects it has on the environment. Throughout the film, Kip speaks with various individuals in the agricultural and environmental world, 
including farmers, and representatives from organizations such as Greenpeace and the Rainforest Action Network. Both myself and Kip clearly share some similar ideals about the need for change within the world of agriculture. However, both our approaches to tackling and portraying the issue on film and the solutions we seek differ. Though this film deals with similar topics and issues that 60 Seasons aims to address, it does so in a very accusatory and negative manner. It throws criticism at the entirety of the agricultural world, and has drawn negative response from some audiences due to statistics and facts that, in hindsight, seem to have potentially been over-embellished and inaccurate. Cowspiracy essentially calls for an end to the entire process of eating meat in order to bring about change in agriculture. Though I personally am a vegetarian, I believe there are ethical and sustainable ways to continue to raise livestock to feed the hungry that don't result in widespread environmental disaster and the gross mistreatment of animals.

My aim with 60 Seasons is to not simply bombard an audience with facts about the damages that factory farming is causing, or to call for an end to livestock farming. Rather, it is a call to reform the way in which the bulk of our crops and livestock are produced, and to hand food production back over from corporate agribusinesses to the individuals, the families, and the sustainably-run farms. It aims to create a compelling and uplifting story about two groups of individuals who are actually taking action to address these issues and are passionate about alternate methods of farming. It strives to show the audience that obtaining food in a sustainable way is not as challenging as one may think, and that personal food 
production is not daunting or scary - it is something that they can take on themselves. 60 Seasons strives to have the audience leave the theatre already thinking of what they will be planting at home when growing season rolls back around, and to be more mindful of where they are buying their food and who is producing it. Unlike Cowspiracy, 60 Seasons' mission is not to motivate people to take action and work towards a change in the food industry by portraying our current model in a negative light only, but to do so by shining a positive light on the people who are already on the forefront of this change.

Along this vein, another documentary that focuses on the change we need to make within our food systems is 2009 film Food, Inc. Created by American filmmaker Robert Kenner, Food, Inc tackles the topic of corporate run farms, and how a few companies now control over $80 \%$ of meat production in the USA. This film deals with a lot of issues that are at the heart of my own film. It tackles the way that agribusinesses are striving to put small, sustainable farms out of business, the growing dangers of the food we eat due to industrial farming's driving motivation of profit leading to the need for uniformity and speed of production of meat, which in turn leads to unsafe conditions and the presence of contaminating bacteria such as E. Coli, and the fact that these methods and dangers are hidden from the public that is consuming these products. Food, Inc lays out the way that food production has changed since the inception of fast food with the first McDonald's restaurant, and the way that the restaurant chain created corporate-like food production within its restaurants. These corporate farms know that the ideal version of agriculture that 
consumers have in their head is the small family farm, with open pastures, animals roaming, sun shining - and they use this ideal in their marketing and packaging, despite the fact that it could not be farther from the truth of how their meat is raised.

Food, Inc aims to put forth the same underlying message of my film - that our current model of corporate run food production is failing us, and failing the planet. However, it depicts this message in a different way from my own documentary. The horrors of the way that animals are raised in factory run farms are shown and focused on in the film. Stories of children who have died from E. Coli contaminated meat are depicted, and images of chickens packed into buildings, never once seeing the sun and unable to stand due to their oversized bodies fill the screen. My film takes a different approach. I don't wish to show the atrocities of industrial farms. I don't want to bombard people with imagery that makes them cringe and look away, which is the reaction that Food, Inc achieved from me upon watching. Instead, my film focuses on the actions of two small groups within a tiny community who are striving to not only produce sustainable produce and livestock for their community, but to spread education about the importance of this method of food production for the health of us all and of our planet.

I believe that showcasing the positive visuals and impact of these farming models that depict the way that food production could, and should, be done is the best approach for 60 Seasons. While Food, Inc shows farmers who seem defeated 
with farms that have been bought out by corporate meat producers, my film shows farmers and community gardens that answer to no one - independently owned and run; positive and hopeful. It is a positive message at its heart. The knowledge is growing about the dangers of factory farming already, and I believe that showing people the practical ways in which they can combat it through two groups of individuals who are doing just that is a much stronger motivator than simply condemning the industrial food production model through disturbing imagery. The negative impact of agribusiness will come across in my film through the interview narration content with both the owners of Headwaters Permaculture Farm and the creator of Punk Rock Produce, but will not be depicted visually. Rather, 60 Seasons is a case study of these two groups of individuals, and a hopeful story of the ways that we can all strive to turn the food industry on it's head, and support both our individual health, and the health and longevity of our planet.

60 Seasons aims to add to a growing conversation around food for those who are already questioning the viability of our current agricultural model, and to start the conversation with those who are unaware. Its goal is to motivate people to continue this conversation amongst their peers well after they have left the theatre. My hope is that seeing individuals taking their food production back into their own hands, being passionate about their food, and encouraging others to do the same, will compel the audience to reevaluate their own food choices, and perhaps stir up a passion to know, and do more themselves. 
As the production of this film continued, the political climate changed quite dramatically. At the time of its conception, 60 Seasons was a film that I believed to be quite relevant and timely, as it is an issue that needs to be addressed and brought to the attention of a wider audience in a world that is aiming to become more environmentally sustainable. However, as my work on the film continued, there was a shift in power in one of the world's major political players - the United States - with the election of Donald Trump. Since that time, I believe the message of this film, and environmentalist films and artistic works in general, is more important than ever. Environmental issues are a major theme in many artistic works coming out at this time, my own included. A clear example of this was present at this year's Scotiabank Contact Photography Festival. The work, titled It's All Happening So Fast, curated by Mirko Zardini and displayed at the Art Museum of the University of Toronto, projects a clear message about the need for environmental change and protection. Its focus is on the Canadian environment, and the exhibition explores a history of Canada's relationship with the land since 194,5 through the use of both historic and contemporary photographs of Canada's landscapes. ${ }^{21}$ The piece stands as a call to action and aims to illustrate the need to take a stand against the rising climate crisis.

Another fellow Canadian artist whose work is strongly geared around environmental protection is photographer Ed Burtynsky. His powerful aerial

\footnotetext{
21 "It's All Happening So Fast - Art Museum at the University of Toronto." Art Museum at the University of Toronto. Accessed 2017. http://artmuseum.utoronto.ca/exhibition/itsall-happening-so-fast/.
} 
photographs depict the Canadian landscape and the ways in which human intervention has changed it in the name of progress, with themes touching on issues such as the oil and mining industries and recycling. ${ }^{22}$ His work titled Water is of particular relevance to my own practice. With this series, Burtynsky showcases various bodies of water and the infrastructure built to manage this resource, and how that water is used - and wasted - around the globe. Burtynsky has said the following of the work - "We have to think more long-term about the consequences of what we are doing, while we are doing it. My hope is that these pictures will stimulate a process of thinking about something essential to our survival, something we often take for granted - until it's gone.". ${ }^{23}$

Burtynsky was of a similar mindset when creating the series Water to my own mindset when creating 60 Seasons. The message of addressing a finite resource - in my case, soil health - before it is too late is an underlying current in both these productions, and also in other environmental art projects being produced at this time. It is discouraging for me and other like-minded individuals to see a shift away from the progress that had been being made towards the protection and sustainability of our planet. The stories around the globe of the damage being inflicted on the earth are multiplying. In Africa, the deforestation threat is immense; Europe's and China's demand for the areas abundant natural resources has created

22 Burtynsky, Edward. "EDWARD BURTYNSKY." Edward Burtynsky. Accessed 2017. http://www.edwardburtynsky.com/.

23 Rosenberg, David. "Incredible Photos of Water." Slate Magazine. September 19, 2013. Accessed 2017.

http://www.slate.com/blogs/behold/2013/09/19/edward_burtynsky_water_examines_one _of_the_world_s_most_precious_resources.html. 
an unsustainable and sometimes even illegal practice that is destroying the biodiversity of the region. ${ }^{24}$

In the North Pacific Ocean, the existence of a collection of debris - primarily consisting of plastics, that is made up of 7 million tons of waste and spans an area of water twice the size of Texas and 9 feet deep - the Great Pacific Garbage Patch stands as a visual representation of how wasteful we are as a society. ${ }^{25}$ And it is not the only garbage patch in our bodies of water - it is simply the largest. In the United States, the practice known as "fracking" breaks up rock formations from deep underground in order to obtain fossil fuels. This process is not only incredibly water-intensive, it is also incredibly water-polluting, as it combines water with toxic chemicals, or "fracking fluid", and injects them deep into the ground, resulting in contaminated water that makes its way into drinking supplies and groundwater. Not only is it clearly more dangerous than renewable energy sources, it is also more expensive. ${ }^{26}$ As issues of global warming and climate change come more to the forefront in political discussions and decisions around the world, the need for positive changes to protect the future of our planet has become much more apparent and recognized.

\footnotetext{
24 "Deforestation in the Congo Basin." WWF. Accessed 2017. http://wwf.panda.org/about_our_earth/deforestation/deforestation_fronts/deforestation_in _the_congo_basin/.

25 "Garbage Patch - Facts." Garbage Patch - The Great Pacific Garbage Patch and other pollution issues. Accessed 2017. http://garbagepatch.net/greatpacificoceangarbagepatchfacts/.

26 "Fracking." Greenpeace USA. Accessed 2017. http://www.greenpeace.org/usa/globalwarming/issues/fracking/.
} 
There is an overwhelming consensus amongst the scientific community on not just the fact that global warming is a real, and dangerous occurrence - but that it is a phenomenon that is overwhelmingly caused by human activities. In fact, a staggering 97 percent of scientists agree on this fact, and endorse this standpoint. ${ }^{27}$ The rate at which global warming is occurring is unprecedented, and its effects are clear around the planet - from the rise in global temperature, the rapid rise of sea levels and the warming and increase of acidification of the world's oceans, to glacial retreat. The issue is not something that we are removed from in Canada. In fact, Canada has warmed at close to twice the global rate alone since 1950, with a change of -1.5 degrees Celsius, as opposed to the average of -0.85 degrees Celsius worldwide, which can be seen in the melting of the permafrost, and in coastal erosion. ${ }^{28}$

As this issue progresses, we see the effects not just in the health of our planet but in human health as well. Evidence has been mounting since 2008 of the effects that climate change is having on human health, and will continue to have if left unchecked. Climate-sensitive diseases, such as Lyme Disease, have been moving further north into Canada, and will continue to do so as global temperatures rise. ${ }^{29}$

\footnotetext{
27 “Climate Change: Vital Signs of the Planet: Evidence.” NASA. Accessed 2017. https://climate.nasa.gov/evidence/

28 "Climate Change and Energy." Friends of the Earth Canada. Accessed 2017. http://foecanada.org/en/issues/climate-change-and-energy/.

${ }^{29}$ Warren, F.J. and Lemmen, D.S. (2014): Synthesis; in Canada in a Changing Climate: Sector Perspectives on Impacts and Adaptation, (ed.) F.J. Warren and D.S. Lemmen; Government of Canada, Ottawa, ON, p. 1-18.
} 
Not only this, but the extreme weather events that occur as a result of global warming - such as wildfires and floods, leave deaths, injuries, and the destruction of communities in their wake. The future of the movement towards environmental change on a political level seemed hopeful as countries united together in the Paris Agreement in December of 2015. This was a worldwide agreement to dramatically reduce emissions, strengthen countries' abilities to deal with the impacts of climate change and to provide support in these areas to developing countries, transparently tracking their progress towards these goals and asking them to be held accountable, and to meet every five years to set even more ambitious targets for the years to come as scientific research and discoveries continue. ${ }^{30}$

This was a monumental achievement - the uniting of almost every country in the world to finally take on the issue of climate change on a scale that could actually bring about the change needed for the sustainability of our planet - and it was celebrated around the globe as such. However, the 2016 election brought on a drastic turn in the way the United States was run with the election of Donald Trump. In May of 2017, a dramatic and much-criticized move by the president saw him calling for the United States to withdraw itself from the Paris Agreement. It is just one string of many since his election that shows his lack of concern for issues surrounding the environment and our planet, and his denial of known science. Amongst his other infractions are the gutting of the EPA's budget and the clearing of accessed 2017, https://ec.europa.eu/clima/policies/international/negotiations/paris_en. 
their climate change website ${ }^{31}$, and his executive orders - one to roll back the Obama-era Clean Power Plan that aimed to reduce carbon dioxide emissions from power plants ${ }^{32}$ and one to weaken the existing Clean Water Act that protects the country's waterways by regulating pollution. ${ }^{33}$ These are simply a few clear examples of Trump's complete neglect for the environment - the list is daunting. With such a major political power being so outspokenly against environmental change, and in fact actively denying that climate change is real - Trump actually calls it a conspiracy theory created by China - we are in a very scary place worldwide, one that could see us taking steps backward over the next four years instead of the desperately-needed steps forward.

In the wake of the troubles facing our planet, 60 Seasons stands as an affirmative body of work that aims to create a positive depiction of sustainability in action. Through the portraits of Tony, Linda and Craig and the passion with which they speak on the subject, it aims to depict how much sense it makes to strive towards these goals on a personal, human level.

\footnotetext{
31 A Running List of How Trump Is Changing the Environment," National Geographic, June 14, 2017, , accessed 2017, http://news.nationalgeographic.com/2017/03/how-trumpis-changing-science-environment/. 32 Ibid.

33 A Running List of How Trump Is Changing the Environment," National Geographic, June 14, 2017, , accessed 2017, http://news.nationalgeographic.com/2017/03/how-trumpis-changing-science-environment/
} 


\section{METHODOLOGY}

60 Seasons is an environmentalist documentary film that creates a video portrait of two growing efforts within the community of Northumberland County that of Headwaters Permaculture Farm, and Punk Rock Produce Community Garden. It does so through sit-down interviews with Tony and Linda Armstrong, founders of Headwaters Farm, and Craig Smith, creator of Punk Rock Produce, along with candid footage of these individuals and their volunteer support at work in the gardens and within their community at large. 60 Seasons_aims to provide a counter-narrative to the corporate run agri-business story that the more you produce, the bigger your fields, the more beef and soy and corn you grow, the more people you feed. It aims to shine a light on the reality that this industrial-run model of agriculture is not sustainable, and will not be able to continue to provide food for the world on a longterm basis.

The film provides a different perspective on farming through the actions and words of Craig, Linda and Tony. It portrays their desire to spread the word about sustainable, healthy methods of farming throughout their community and the world at large, and to encourage others to partake in actions to help support not only healthy growing methods, but the food security of their own communities as well. The film is as much a portrait piece as it is an environmentalist one. It aims to tell the story of these individuals, their passions and motivations, and create a picture of the community within which they live. 
From its beginnings, 60 Seasons has truly been a passion project for me, one that has grown, changed, and adapted as I progressed my way through the early stages of planning and shooting. The first seeds of the project originally started growing when I was working on my undergrad thesis for my BFA in Photography from Ryerson University. During my final term, I created a series of still images that documented the life of a young couple who purchased 80 acres of land in the small community of Yarker, Ontario. They built a 700-square-foot straw bale insulated home and began growing a sustainable livestock farm to feed their community from the ground up. Their story was one that I was fascinated by. Building a sustainable home and being more involved in the production of the food that I eat is something that has always been a desire of mine, so naturally I was drawn to this subject.

When entering into my MFA at Ryerson, I applied with this same photo series, titled Fat of the Land, with the intention of continuing to further tell the story of Justin and Andrea and their farm. This was the basic beginnings of 60 Seasons. Video work was a new field for me, and one that I was nervous to enter. My original plan for my thesis was to create a combination of still images and short video vignettes, creating a more experimental, poetic style of film, rather than one with a straight narrative that was solely video-based. I spent the start of the program experimenting with this idea. I visited Fat of the Land farm and worked on documenting specific moments in their life in both stills and video. I wanted the documentary to be personal to the two of them, while still creating a story that gave 
viewers insight into how they had made living off the land a reality for themselves. I wanted to provide information to a curious audience who wanted to be able to live more sustainably themselves, while still creating an interesting and personal story.

That was the heart of what I wanted to accomplish with my thesis work. As I began exploring more of the documentary world, I originally found myself drawn to the idea of turning Fat of the Land into an interactive, online documentary experience. I found inspiration for this idea by exploring other online documentary projects such as Climate Wisconsin - an interactive documentary highlighting small stories and vignettes of small community farming experiences through audio narration, still images and video clips ${ }^{34}$. I admired that this piece was able to create small stories that the audience could explore and digest one at a time, in small sittings or longer explorations, and the fact that the audience could experience an interesting and engaging story, while at the same time learn valuable information about the farming lifestyle if they chose to explore that avenue more themselves.

However, as I progressed through the program, both my idea and my methodology for creating it began to shift. It started with a feeling of stagnation, that focusing on Fat of The Land farm, a project I had already devoted so much time of my undergrad to, was feeling somewhat stale. I wanted to start a project that I could take on from its beginning - create something fresh for both myself and my

\footnotetext{
34 "Climate Wisconsin," Home I Climate Wisconsin, , accessed 2017, https://climatewisconsin.org/.
} 
audience. But the ideals behind Fat of The Land were still ones that I wanted to pursue, even as the specific subject of the documentary changed. There were many projects beginning to emerge that were highlighting individuals who were living off the land. I wanted to tell a story that was different and unique. By taking a closer look at the work and what my motivations were behind it, I was able to parse out what my primary concern with telling that story was.

I had always been passionate about environmentalism and sustainable living. It was during a sociology of food class from my undergrad years that I began to learn the real dangers of our current food systems, and the real need for change to both support the future of the planet, and the food security of individuals around the globe. I realized that this was the key element from Fat of The Land that I was the most connected with. I wanted to showcase individuals who were taking healthy and sustainable food production back into their own hands, and show that change was possible. Small scale efforts can evolve and grow into something bigger than themselves, and even the smallest of efforts makes a difference within a community - and eventually, when combined and spread, can make an impact globally. With this in mind, I began developing a new project - one that would become 60 Seasons.

I liked the idea of focusing on my own community, and already knew of two efforts within Northumberland that shared the ideals and values that I wanted to highlight in the film. Punk Rock Produce is a community garden in it's very first year, whose aim is to provide quality, organically-grown produce to our local food 
bank while making use of valuable, unused space within the downtown core to produce food, and acting as a hub to educate the community on the ease with which they could grow their own food as well. Headwaters Permaculture Farm had similar goals - to provide educational opportunities around permaculture and sustainability, and also to provide healthy, organically and ethically grown food to their community. These were the two organizations that would play out in the final iteration of the film, but originally I had planned to include a third element as well Cultivate. Cultivate is a food festival that celebrated its second year in 2016. It is held in Port Hope, Ontario, and celebrates local, organically-grown food through food vendors and educational seminars. This element was eventually cut from the final film. It had simply become too busy, there were too many characters involved, and the festival, while wonderful, didn't add a lot to the conversation around the desire and need to support sustainable methods of farming.

After discussion with peers and classmates, I decided that removing the festival from the film was the best course of action in order to streamline my message within the confines of a short documentary film. This brings me to the change in format of the documentary work.

As stated, during the preliminary stages, I had been planning to create an online, interactive documentary that combined still images and video. With the new direction of the subject matter of the piece, the format with which I would tell the story shifted as well. With much discussion, I decided that a structured film 
would be the best method to tell my story. There was a message that I wanted to convey, and a story about individuals that I wanted to come through. I wanted the audience to be able to take away that message after one viewing of the project, and I worried that with an interactive piece, viewers could see bits and pieces of the story and then move on, without the real message being conveyed to them. I decided it would be much more powerful, and more effective to create a piece with a narrative that is watched and absorbed from beginning to end in one sitting, in the way I want it to be told.

Going forward in the future, I would still like to create a supplementary, perhaps interactive, online component to the project. This would simply serve as a means for people who are interested in adopting some of the practices discussed in the film, or learning more about the issues it addresses, to have a resource to find more information than is able to be provided in the short documentary format of the film. But, unlike the original plan, the film itself is the core of the piece, rather than an online interactive documentary.

Coming into film making with no prior experience in video work, but a background in still photography, I knew I wanted my film to be visually engaging to have footage that felt alive and active and which kept the audience entertained while still conveying an important message. For this end, I wanted to keep the actual visuals of the interview footage to a relative minimum and not have a finished piece that was primarily talking heads. Because of this, I spent the majority of the 
summer on location at both Headwaters and Punk Rock Produce shooting all of the goings-on and the live action practices of the issues and techniques that would be discussed in the interviews, in order to have lots of interesting footage to work with alongside the audio of the interviews. Thankfully, I had met both Tony and Craig briefly previously, and upon approaching them with the idea of the film, both were incredibly enthusiastic and excited to be a part of it. This allowed me amazing access to both initiatives, with each of them telling me I was welcome to show up and film at any time. Tony and Linda both had a wealth of knowledge about both the themes and message of the film, and also in its creation, as both of them come from a media production background. It was because of all of the subjects' openness and enthusiasm about the film that it was able to become the work that it is, and progress naturally into the story that developed from the original idea of Fat of the Land, into it's final form as 60 Seasons.

The main challenge in the production of 60 Seasons was, for me, in the editing room. Tackling a film was a big change from shooting still images not just in the original production, but in the piecing together of the final product. Many hours were spent transcribing days and days of footage and interviews in order to piece together the narrative that I wanted to tell. Keeping it within a 30 minute time frame also proved to be quite daunting - there were so many things to say with the film and so many points that I wanted to touch on. Honing in on the most important elements and message of the film, and then creating a narrative flow to touch on all of those issues both took an incredible amount of time and patience. In the end, I 
wanted the focus to be on the story of these three individuals, and the ideals that they hold - food security for their community, the support of small farms, and ethical and sustainable food production. I began with this mentality in mind and used that to first build a paper edit of the interviews that I then built into the audio narration backbone of the film. I had endless hours of action footage or b-roll to use on top of this narration so it was a hard process to choose the best shots and the most fitting visuals to go along with this underlying story. Whenever I take on something new, I tend to throw myself into the deep end. This film was no exception. Despite my lack of experience, I decided to take on the entire editing process myself - including colour grading, story editing and cleaning up all the audio. This was more of a hurdle than I thought it would be when I made the decision, but with lots of advice, and many tutorials watched, it ended up coming together into something cohesive that I am quite proud of. And I am glad to have these new skills to make use of when moving forward with future film projects. 


\section{APPENDIX}

Total food bank use in March

by province.

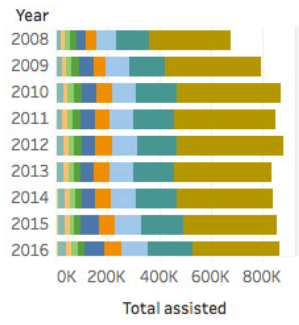

Province

Territories

British Columbia

Prince Edward Island Quebec

Saskatchewan Ontario

New Brunswick

Nova Scotia

Newfoundland and Labra... Source: Food Banks Canada's

Alberta annual Hunger Count report 2008

Manito 2016

\section{How has food bank use changed since $2008 ?$}

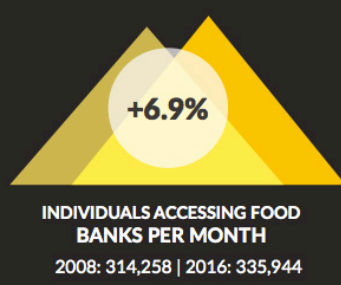

2008 FIGURES

2016 FIGURES

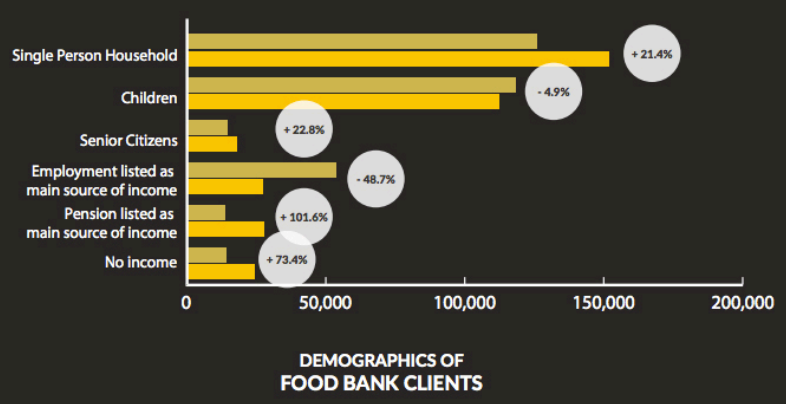


Fig 4.

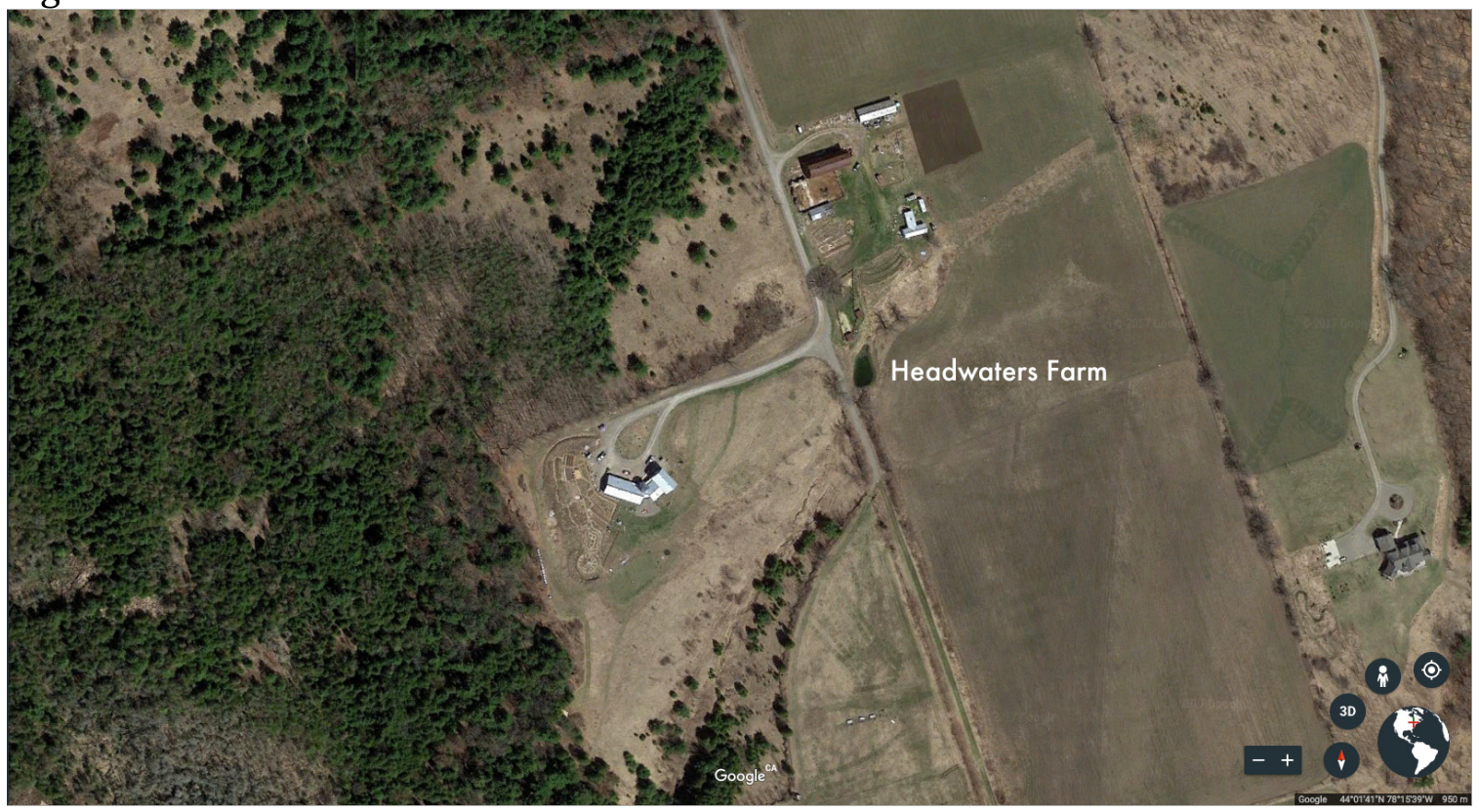

Fig 5.

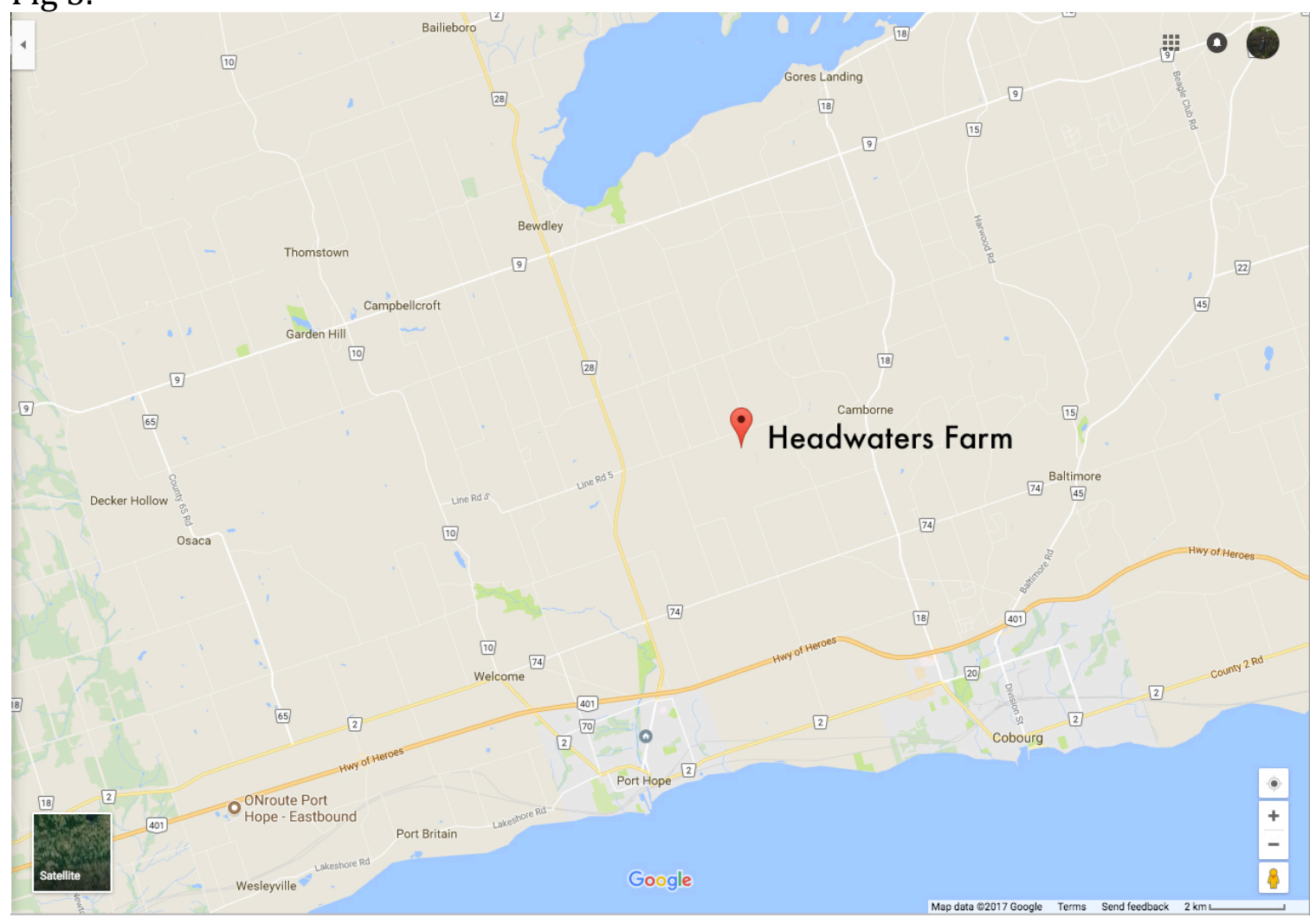


Fig 6.

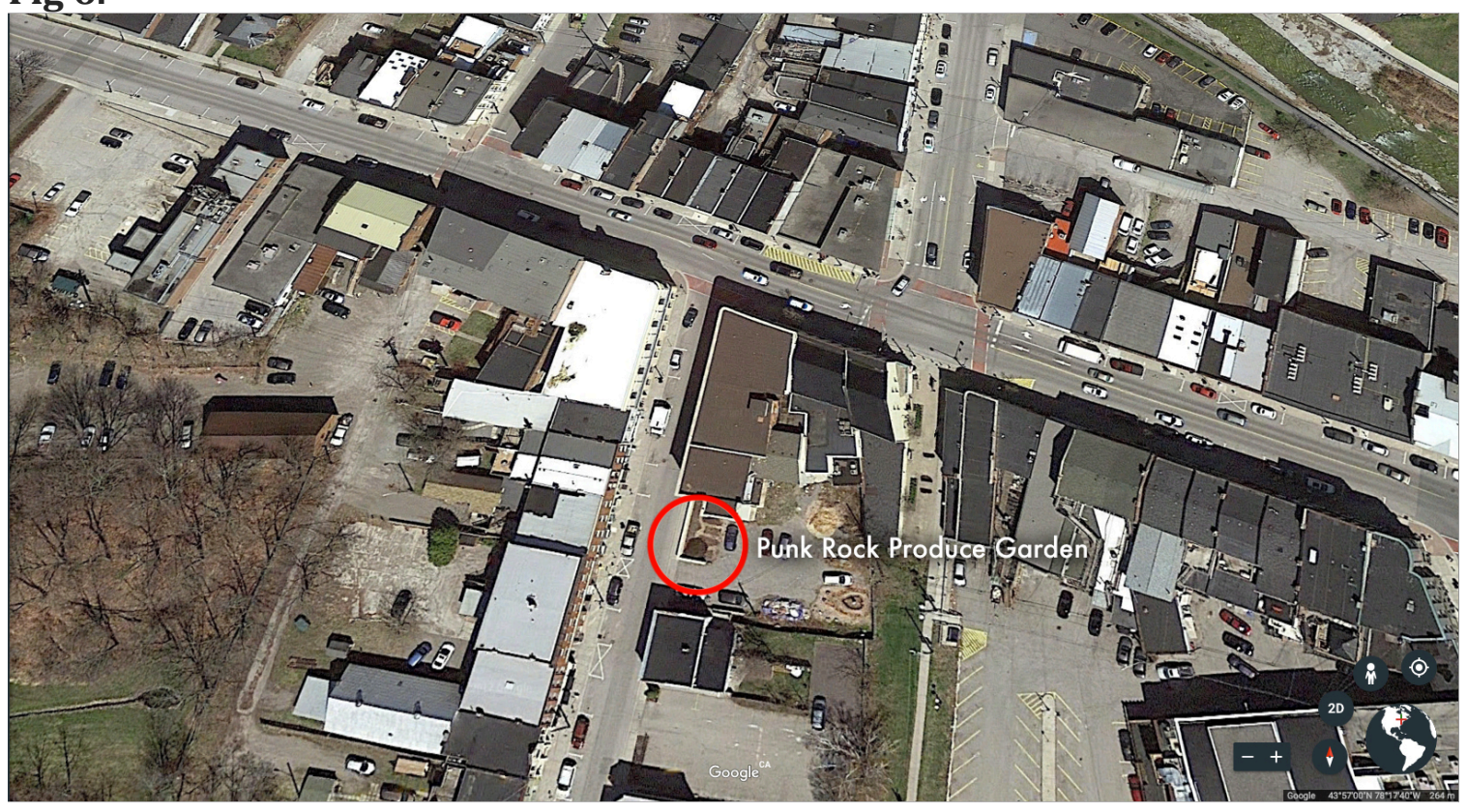

Fig 7.

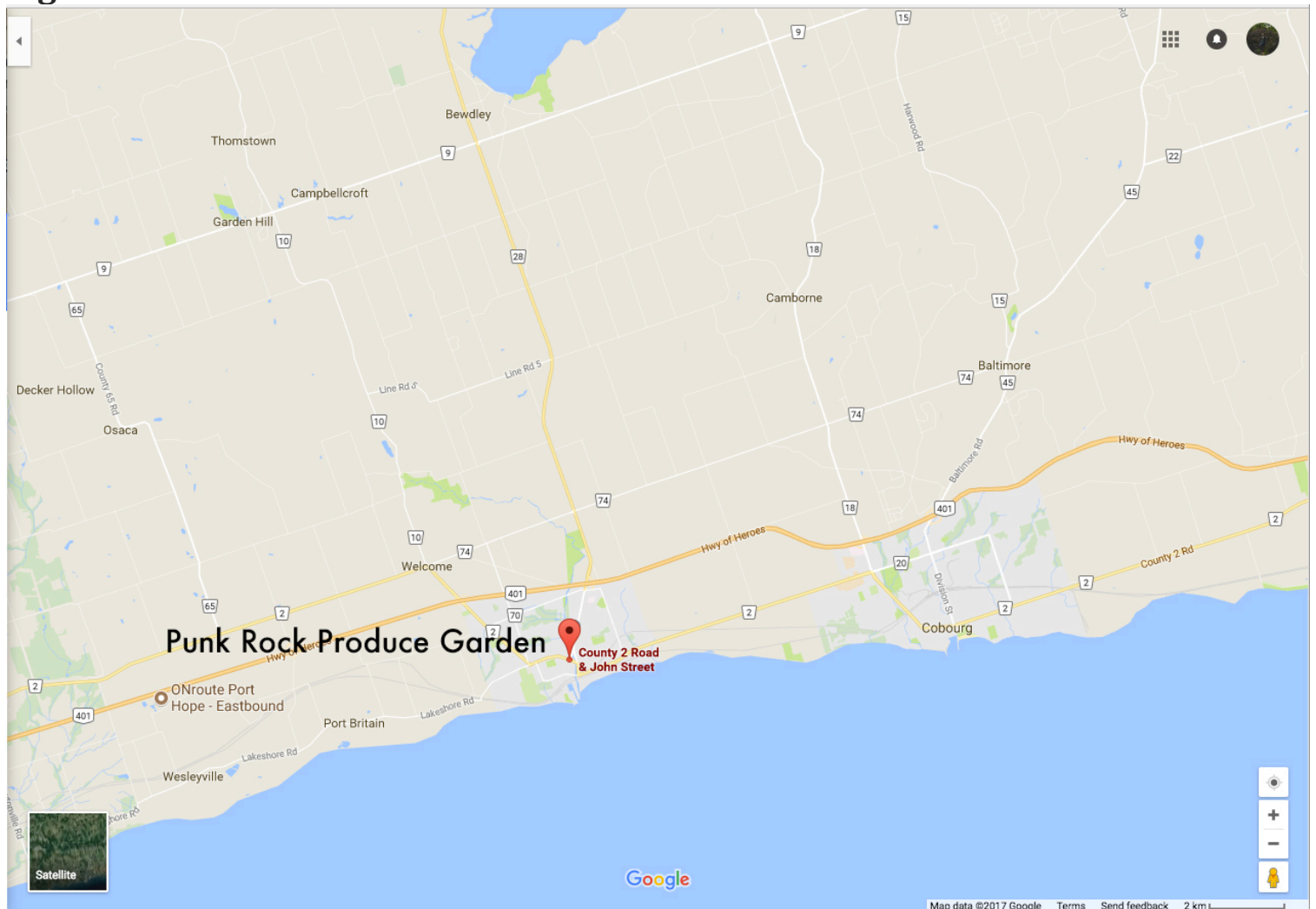




\section{WORKS CITED}

"A Running List of How Trump Is Changing the Environment." National Geographic. June 14, 2017. Accessed 2017. http://news.nationalgeographic.com/2017/03/how-trumpis-changing-science-environment/.

Arsenault, Chris. "Only 60 Years of Farming Left If Soil Degradation Continues." Scientific American. 2014. https://www.scientificamerican.com/article/only-60-years-offarming-left-if-soil-degradation-continues/.

Belott, Anne. "Modeling Sustainable Food Systems - The Permaculture Research Institute." The Permaculture Research Institute. 2016. http://permaculturenews.org/2016/11/24/modeling-sustainable-food-systems/.

Bjørkhaug, H., Ronningen, K. (2011). Global Shocks, Changing Agricultural Policy and the Viability of Rural Communities. International Journal of Sociology of Agriculture and Food, Volume 21, 1-6

Bortman, Marci, Peter Brimblecombe, and Mary Ann Cunningham. "Permaculture." Environmental Encyclopedia , Vol. 2. 3rd ed. Detroit: Gale, 2003. p1065-1067. 2003.

Burtynsky, Edward. "EDWARD BURTYNSKY." Edward Burtynsky. Accessed 2017. http://www.edwardburtynsky.com/.

"Climate Change and Energy." Friends of the Earth Canada. Accessed 2017. http://foecanada.org/en/issues/climate-change-and-energy/.

“Climate Change: Vital Signs of the Planet: Evidence.” NASA. Accessed 2017. https://climate.nasa.gov/evidence/

“Climate Wisconsin,” Home I Climate Wisconsin, accessed 2017, https://climatewisconsin.org

Cowspiracy: The Sustainability Secret. Directed by Kip Andersen and Keegan Kuhn. USA: A.U.M. Films, June 26th, 2014.

"Deforestation in the Congo Basin." WWF. Accessed 2017. http://wwf.panda.org/about_our_earth/deforestation/deforestation_fronts/deforestation_in _the_congo_basin/.

FAO. "Soils Are the Foundation for Vegetation." (PDF File). Food and Agriculture Organization of the United Nations. 2015. http://www.fao.org/3/a-i4666e.pdf. 
FAO. Status of the World's Soil Resources. Food and Agriculture Organization of the United Nations, 2015. 2015. http://www.fao.org/documents/card/en/c/c6814873-efc341db-b7d3-2081a10ede50/.

Food Banks Canada (2016). HungerCount 2016. Toronto: Food Banks Canada.

"Food Banks Canada." Food Banks Canada. 2016. https://www.foodbankscanada.ca/.

Food, Inc. Directed by Robert Kenner. USA: Magnolia Pictures, 2008.

"Fracking." Greenpeace USA. Accessed 2017. http://www.greenpeace.org/usa/globalwarming/issues/fracking/.

"Garbage Patch - Facts." Garbage Patch - The Great Pacific Garbage Patch and other pollution issues. Accessed 2017.

http://garbagepatch.net/greatpacificoceangarbagepatchfacts/.

"It's All Happening So Fast - Art Museum at the University of Toronto." Art Museum at the University of Toronto. Accessed 2017. http://artmuseum.utoronto.ca/exhibition/itsall-happening-so-fast/.

Kimbrell, Andrew. The Fatal Harvest Reader: The Tragedy of Industrial Agriculture. Washington: Published by the Foundation for Deep Ecology in Collaboration with Island Press, 2002.

Koç, M., Sumner, J., Winson, A. (2012). Critical Perspectives in Food Studies. Don Mills, Ontario: Oxford University Press.

"Paris Agreement." Climate Action - European Commission. February 16, 2017. Accessed 2017. https://ec.europa.eu/clima/policies/international/negotiations/paris_en.

Rosenberg, David. "Incredible Photos of Water." Slate Magazine. September 19, 2013. Accessed 2017. http://www.slate.com/blogs/behold/2013/09/19/edward_burtynsky_water_examines_one _of_the_world_s_most_precious_resources.html.

Scanlan, S.T. (2013) Feeding the Planet or Feeding Us a Line? Agribusiness, "Grainwashing" and Hunger in the World Food System. International Journal of Sociology of Agriculture and Food, Volume 20, 357-382

Tarasuk, Valerie, Dachner, Naomi, Loopstra, Rachel, (2014),"Food banks, welfare, and food insecurity in Canada", British Food Journal, Vol. 116 Iss 9 pp. 1405 - 1417 
Viegas, I., Santos, J. M. L., Barreto, A., Fontes, M.A. (2011). Meat Safety: A Brief Review of Concerns Common to Science and Consumers. International Journal of Sociology of Agriculture and Food, Volume 19, 275-288

Warren, F.J. and Lemmen, D.S. (2014): Synthesis; in Canada in a Changing Climate: Sector Perspectives on Impacts and Adaptation, (ed.) F.J. Warren and D.S. Lemmen; Government of Canada, Ottawa, ON, p. 1-18. 


\section{ADDITIONAL RESOURCES}

\section{WWOOFing}

https://www.workaway.info/

http://wwoof.net/

Headwaters

https://headwatersfarm.ca/

Punk Rock Produce

http://www.punkrockproduce.ca/

\section{Permaculture}

http://www.eonpermaculture.ca/

https://permaculture.org/ 